\title{
Stabilization of Long Cationic EMACs by Reduction or Loss of One Metal Ion
}

\author{
Rayyat H. Ismayilov, ${ }^{[a, b]}$ Wen-Zhen Wang, ${ }^{[a, b]}$ Rui-Ren Wang, ${ }^{[a]}$ Yi-Lin Huang, ${ }^{[c]}$ \\ Chen-Yu Yeh, ${ }^{[c]}$ Gene-Hsiang Lee, ${ }^{[a]}$ and Shie-Ming Peng ${ }^{*[a, b]}$
}

Keywords: Metal-metal interactions / N ligands / Nickel / Magnetic properties

The new pyrimidyl- and naphthyridyl-modulated pentapyridyltetramine ligand $\left(\mathrm{H}_{3} \mathrm{~N}_{9}-2 \mathrm{pm}\right)$ and its linear nona- and octanickel chain complexes were successfully synthesized. The nonanickel complex $\left[\mathrm{Ni}_{9}\left(\mu_{9}-\mathrm{N}_{9}-2 \mathrm{pm}\right)_{4} \mathrm{Cl}_{2}\right]\left(\mathrm{PF}_{6}\right)_{2}$ (1) contains two fully delocalized, mixed-valence $\left.\left[\mathrm{Ni}_{2} \text { (napy) }\right)_{4}\right]^{3+}$ units. Magnetic measurements performed on the defective octanu- clear complex $\left[\mathrm{Ni}_{8}\left(\mu_{8}-\mathrm{N}_{9}-2 \mathrm{pm}\right)_{4} \mathrm{Cl}_{2}\right]\left(\mathrm{PF}_{6}\right)_{2}$ (2) demonstrate that the metal chain provides a pathway of magnetic superexchange coupling over the extended metal atom chain (EMAC).

() Wiley-VCH Verlag GmbH \& Co. KGaA, 69451 Weinheim, Germany, 2008)

\section{Introduction}

Extended metal atom chain (EMAC) complexes are very important to provide a fundamental understanding of metal-metal interactions. They seem to be suitable substances for potential applications such as molecular metal wires and switches. ${ }^{[1]}$ Typical EMACs consist of a linear metal chain and four supporting ligands which are helically wrapped around the metal core with all the pyridine nitrogen and amido nitrogen atoms coordinated in a syn form. By employing oligo- $\alpha$-pyridylamino ligands, tri-,${ }^{[2]}$ tetra- $-{ }^{[3]}$ penta-,${ }^{[4]}$ hepta-,${ }^{[5]}$ and nonanuclear ${ }^{[6]}$ EMACs have been synthesized and studied. It is theoretically possible to extend the system to an infinite one-dimensional molecule. For this purpose, the synthesis of longer EMACs than those currently produced is one of our research targets. With an increasing number of metal atoms in EMACs, however, the synthetic difficulty increases and the yield decreases. Recently, we developed a new family of ligands by including pyrazine or pyrimidine instead of pyridine ring(s) in the supporting ligands. ${ }^{[7]} \mathrm{By}$ introducing nitrogen-rich aromatic ring(s) to the supporting ligands, the yields of the resulting EMACs were improved significantly, and the complexes obtained were more resistant to oxidation than the corresponding oligo- $\alpha$-pyridylamino EMACs. The longest chromium(II) and cobalt(II) EMACs, $\left[\mathrm{Cr}_{9}\left(\mu_{9}-\mathrm{N}_{9}-\mathrm{mpz}\right)_{4} \mathrm{X}_{2}\right]^{[6 \mathrm{~b}]}$ and $\left[\mathrm{Co}_{7}\left(\mu_{7}-\mathrm{L}\right)_{4} \mathrm{X}_{2}\right]\left(\mathrm{L}=\mathrm{pzpz}^{3-}\right.$ and $\mathrm{tpz}^{3-}, \mathrm{X}=\mathrm{Cl}^{-}$and

[a] Department of Chemistry, National Taiwan University, Taipei, Taiwan, ROC

E-mail: smpeng@ntu.edu.tw

[b] Institute of Chemistry, Academia Sinica, Taipei,Taiwan, ROC

[c] Department of Chemistry, National Chung Hsing University, Taichung, Taiwan, ROC

Supporting information for this article is available on the WWW under http://www.eurjic.org or from the author.
$\left.\mathrm{NCS}^{-}\right),{ }^{[5 c]}$ were successfully obtained with this strategy. In addition, it has been known for many years that the use of naphthyridine-modulated ligands gives rise to mixed-valent nickel complexes and thus stabilizes nickel complexes with a low oxidation state. ${ }^{[8]}$ Therefore, we designed a new series of naphthyridine-modulated oligo- $\alpha$-pyridylamino ligands and synthesized the corresponding EMACs with redox properties that are very different from those of the oligo- $\alpha$ pyridylamino EMACs. ${ }^{[9]}$ Herein we report a new pyrimidine- and naphthyridine-modulated oligo- $\alpha$-pyridylamino ligand, $N^{2}$-(pyrimidin-2-yl)- $N^{7}$-[2-(pyrimidin-2-ylamino)-1,8naphthyridin-7-yl]-1,8-naphthyridine-2,7-diamine $\left(\mathrm{H}_{3} \mathrm{~N}_{9}\right.$ $2 \mathrm{pm})$ and its nickel EMAC complexes $\left[\mathrm{Ni}_{9}\left(\mu_{9}-\mathrm{N}_{9}-2 \mathrm{pm}\right)_{4}{ }^{-}\right.$ $\left.\mathrm{Cl}_{2}\right]\left(\mathrm{PF}_{6}\right)_{2}(\mathbf{1})$ and $\left[\mathrm{Ni}_{8}\left(\mu_{8}-\mathrm{N}_{9}-2 \mathrm{pm}\right)_{4} \mathrm{Cl}_{2}\right]\left(\mathrm{PF}_{6}\right)_{2}(\mathbf{2})$.

\section{Results and Discussion}

\section{Syntheses and Structures}

The ligand $\mathrm{H}_{3} \mathrm{~N}_{9}-2 \mathrm{pm}$ was synthesized on the basis of the palladium-catalyzed Buchwald procedure by the crosscoupling of bis(2-chloro-1,8-naphthyridin-7-yl)amine and 2-aminopyrimidine (Scheme 1).

A nonanuclear complex, $\left[\mathrm{Ni}_{9}\left(\mu_{9}-\mathrm{N}_{9}-2 \mathrm{pm}\right)_{4} \mathrm{Cl}_{2}\right]\left(\mathrm{PF}_{6}\right)_{2}(\mathbf{1})$, and an octanuclear complex, $\left[\mathrm{Ni}_{8}\left(\mu_{8}-\mathrm{N}_{9}-2 \mathrm{pm}\right)_{4} \mathrm{Cl}_{2}\right]-$ $\left(\mathrm{PF}_{6}\right)_{2}$ (2), were synthesized by the reaction of anhydrous $\mathrm{NiCl}_{2}$ with the ligand $\mathrm{H}_{3} \mathrm{~N}_{9}-2 \mathrm{pm}$ in a naphthalene solution and in an argon atmosphere. $t \mathrm{BuOK}$ was used as a base to deprotonate the amine groups. The nona- and octanuclear complexes can be successfully synthesized by carefully controlling the reaction temperature, the metal-ligand ratio, and the purification methods. Figure 1 and Figure 2 show the ORTEP drawings of complexes $\mathbf{1}$ and $\mathbf{2}$, respectively. Selected bond lengths and angles are listed in Table 1. 


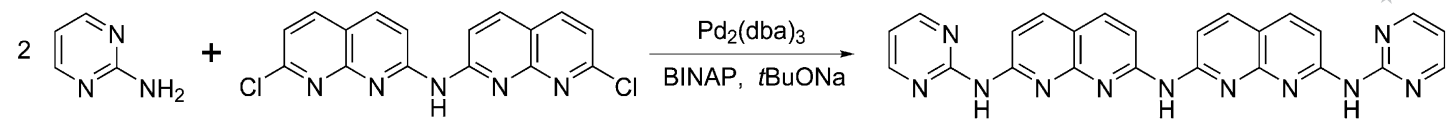

Scheme 1. Synthesis of $\mathrm{H}_{3} \mathrm{~N}_{9}-2 \mathrm{pm}$.

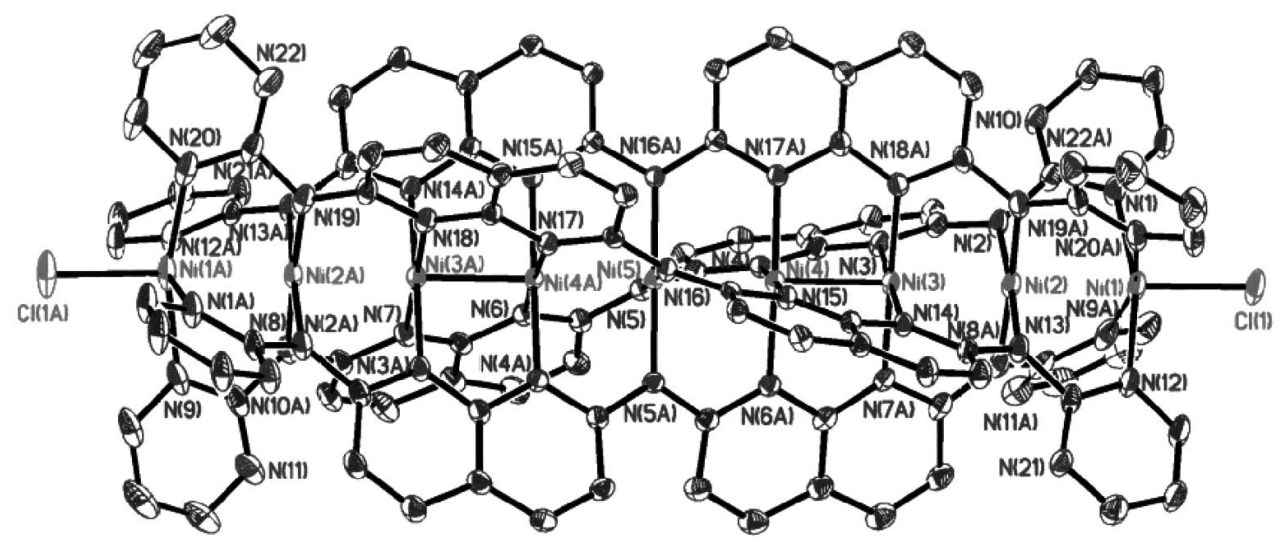

Figure 1. The molecular structures of the dicationic complex in $\left[\mathrm{Ni}_{9}\left(\mu_{9}-\mathrm{N}_{9}-2 \mathrm{pm}\right)_{4} \mathrm{Cl}_{2}\right]\left(\mathrm{PF}_{6}\right)_{2}(\mathbf{1})$. Thermal ellipsoids are drawn at the $30 \%$ probability level. Hydrogen atoms have been omitted for clarity.

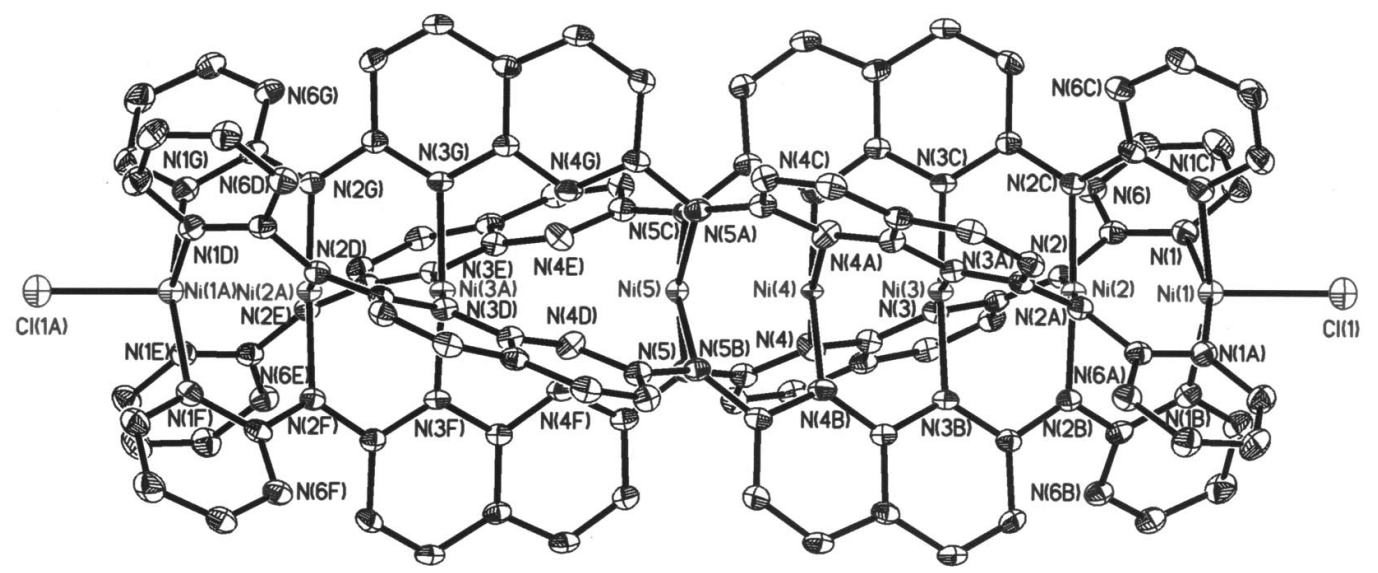

Figure 2. The molecular structure of the dicationic complex in $\left[\mathrm{Ni}_{8}\left(\mu_{8}-\mathrm{N}_{9}-2 \mathrm{pm}\right)_{4} \mathrm{Cl}_{2}\right]\left(\mathrm{PF}_{6}\right)_{2}(2)$. The occupancy of $\mathrm{Ni}(4)$ and $\mathrm{Ni}(5)$ is $50 \%$ and $\mathrm{Ni}(4 \mathrm{~A})$ and $\mathrm{Ni}(5 \mathrm{~A})$ are omitted. Thermal ellipsoids are drawn at the $30 \%$ probability level. Hydrogen atoms have been omitted for clarity.

Both $\mathbf{1}$ and $\mathbf{2}$ are dicationic complex molecules, each containing two $\mathrm{PF}_{6}{ }^{-}$molecules as counteranions. As seen in Figure 1 and Figure 2, the complexes have an EMAC structure with four deprotonated supporting ligands $\mathrm{N}_{9}-2 \mathrm{pm}^{3-}$ wrapped around the linear metal chain in a syn-syn form as trianion helices; the axial chloride ions bond to the terminal nickel atoms are collinear with the metal chain. Both molecules, $\mathbf{1}$ and 2, each have a length of $23 \AA$. These are the longest EMAC complexes obtained since $\left[\mathrm{Ni}_{9}\left(\mu_{9} \text {-peptea }\right)_{4}\right.$ $\left.\mathrm{Cl}_{2}\right]$ and $\left[\mathrm{Cr}_{9}\left(\mu_{9}-\mathrm{N}_{9}-\mathrm{mpz}\right)_{4} \mathrm{X}_{2}\right]\left(\mathrm{X}=\mathrm{Cl}^{-}\right.$and $\left.\mathrm{NCS}^{-}\right)$were reported. ${ }^{[6]}$

The crystal structure of molecule $\mathbf{1}$ has a twofold symmetry axis which is perpendicular to the nickel chain and goes through the central nickel atom. The dication in $\mathbf{1}$ consists of nine nickel atoms in a nearly linear arrangement with $\mathrm{Ni-Ni-Ni}$ bond angles in the range $178-180^{\circ}$. It is noticeable that $\mathbf{1}$ is actually two-electron-reduced with a $\mathrm{Ni}_{9}{ }^{16+}$ core. The $\mathrm{Ni}-\mathrm{Ni}$ distances range from 2.2250 to $2.4055 \AA$ and show a decreasing trend from terminal to the center, the terminal distance $[\mathrm{Ni}(1)-\mathrm{Ni}(2)]$ being the longest. However, the distance between two nickel atoms bonded to naphthyridyl units, [Ni(3)-Ni(4); 2.2250(3) $\AA]$, is slightly shorter than the distance $\mathrm{Ni}(4)-\mathrm{Ni}(5)$ [2.2817(6) $\AA]$. Crystallographic analysis of compound $\mathbf{1}$ reveals a partial metal-metal bond between the $\mathrm{Ni}(3)$ and $\mathrm{Ni}(4)$ ions, which was also observed in hexanickel EMACs. ${ }^{[9]}$ This means that the two extra electrons are reasonably located on the nickel atoms bonded to 1,8 -naphthyridyl moieties to form $\left[\mathrm{Ni}_{2}-\right.$ (napy) $\left.)_{4}\right]^{3+}$ units in $\mathbf{1}$. Thus, the charge distribution in the metal chain of $\mathbf{1}$ is described as $\mathrm{Ni}^{\mathrm{II}}-\mathrm{Ni}^{\mathrm{II}}-\mathrm{Ni}_{2}{ }^{\mathrm{III}}-\mathrm{Ni}^{\mathrm{II}}-$ $\mathrm{Ni}_{2}{ }^{\mathrm{III}}-\mathrm{Ni}^{\mathrm{II}}-\mathrm{Ni}^{\mathrm{II}}$, in which $\mathrm{Ni}_{2}{ }^{\mathrm{III}}$ represents a fully delocalized, mixed-valent $\left[\mathrm{Ni}_{2}(\text { napy })_{4}\right]^{3+}$ unit. ${ }^{[8 b]}$ The $\mathrm{Ni}(3)-\mathrm{Ni}(4)$ 
Table 1. Selected bond lengths $(\AA)$ and angles $\left({ }^{\circ}\right)$ of compounds 1 and 2 [a]

\begin{tabular}{llll}
\hline $\mathbf{1}$ & & & \\
\hline $\mathrm{Ni}(1)-\mathrm{Ni}(2)$ & $2.4055(9)$ & $\mathrm{Ni}(2)-\mathrm{Ni}(3)$ & $2.3012(9)$ \\
$\mathrm{Ni}(3)-\mathrm{Ni}(4)$ & $2.2250(9)$ & $\mathrm{Ni}(4)-\mathrm{Ni}(5)$ & $2.2817(6)$ \\
$\mathrm{Ni}(1)-\mathrm{N}_{\mathrm{av}}$ & $2.083(6)$ & $\mathrm{Ni}(2)-\mathrm{N}_{\mathrm{av}}$ & $1.919(6)$ \\
$\mathrm{Ni}(3)-\mathrm{N}_{\mathrm{av}}$ & $2.002(5)$ & $\mathrm{Ni}(4)-\mathrm{N}_{\mathrm{av}}$ & $2.010(4)$ \\
$\mathrm{Ni}(5)-\mathrm{N}_{\mathrm{av}}$ & $1.943(4)$ & $\mathrm{Ni}(1)-\mathrm{Cl}$ & $2.2942(16)$ \\
$\mathrm{Ni}(1)-\mathrm{Ni}(2)-\mathrm{Ni}(3)$ & $179.61(5)$ & $\mathrm{Ni}(2)-\mathrm{Ni}(3)-\mathrm{Ni}(4)$ & $179.69(4)$ \\
$\mathrm{Ni}(3)-\mathrm{Ni}(4)-\mathrm{Ni}(5)$ & $179.60(4)$ & $\mathrm{Ni}(4 \mathrm{~A})-\mathrm{Ni}(5)-\mathrm{Ni}(4)$ & $179.99(5)$ \\
$\mathrm{Cl}(1)-\mathrm{Ni}(1)-\mathrm{Ni}(2)$ & $178.30(7)$ & & \\
$\mathrm{N}-\mathrm{Ni}(1)-\mathrm{Ni}(2)-\mathrm{N}$ & 24.04 & $\mathrm{~N}-\mathrm{Ni}(2)-\mathrm{Ni}(3)-\mathrm{N}$ & 15.43 \\
$\mathrm{~N}-\mathrm{Ni}(3)-\mathrm{Ni}(4)-\mathrm{N}$ & 13.49 & $\mathrm{~N}-\mathrm{Ni}(4)-\mathrm{Ni}(5)-\mathrm{N}$ & 13.96 \\
\hline $\mathbf{2}$ & & & \\
\hline $\mathrm{Ni}(1)-\mathrm{Ni}(2)$ & $2.4074(19)$ & $\mathrm{Ni}(2)-\mathrm{Ni}(3)$ & $2.3323(18)$ \\
$\mathrm{Ni}(3)-\mathrm{Ni}(4)$ & $2.2520(3)$ & $\mathrm{Ni}(4)-\mathrm{Ni}(5)$ & $2.351(3)$ \\
$\mathrm{Ni}(1)-\mathrm{N}_{\mathrm{av}}$ & $2.097(5)$ & $\mathrm{Ni}(2)-\mathrm{N}_{\mathrm{av}}$ & $1.902(4)$ \\
$\mathrm{Ni}(3)-\mathrm{N}_{\mathrm{av}}$ & $1.918(4)$ & $\mathrm{Ni}(4)-\mathrm{N}_{\mathrm{av}}$ & $1.978(5)$ \\
$\mathrm{Ni}(5)-\mathrm{N}_{\mathrm{av}}$ & $1.969(6)$ & $\mathrm{Ni}(1)-\mathrm{Cl}$ & $2.3290(3)$ \\
$\mathrm{N}-\mathrm{Ni}(1)-\mathrm{Ni}(2)-\mathrm{N}$ & 22.25 & $\mathrm{~N}-\mathrm{Ni}(2)-\mathrm{Ni}(3)-\mathrm{N}$ & 18.92 \\
$\mathrm{~N}-\mathrm{Ni}(3)-\mathrm{Ni}(4)-\mathrm{N}$ & 19.16 & $\mathrm{~N}-\mathrm{Ni}(4)-\mathrm{Ni}(5)-\mathrm{N}$ & 15.82
\end{tabular}

[a] $\mathrm{Ni}-\mathrm{N}_{\mathrm{av}}$ : average value from the four wrapping ligands: $\mathrm{A}$ : $-x-1, y,-z+1 / 2$. (Symmetry operation for compound $\mathbf{1}$ ).

bond length is significantly shorter than the $\mathrm{Ni}-\mathrm{Ni}$ bond lengths in the mixed-valent complexes $\left[\mathrm{Ni}_{2}(\text { napy })_{4} \mathrm{X}_{2}\right]^{+}$ (napy $=1,8$-naphthyridine) $[\mathrm{Ni}-\mathrm{Ni}$ distance $2.415(4) \AA$ for $\mathrm{X}=\mathrm{Br}^{-}$and 2.405(4) $\AA$ for $\left.\mathrm{X}=\mathrm{I}^{-}\right],{ }^{[8,9]}$ which suggests a dinickel unit $\left(\mathrm{Ni}_{2}{ }^{\mathrm{III}}\right)$ with a spin state $S=1 / 2$. The terminal $\mathrm{Ni}^{\mathrm{II}}$ atoms are five-coordinate and the $\mathrm{Ni}-\mathrm{N}$ distance [2.081(6) $\AA$ for $\mathrm{Ni}(1)-\mathrm{N}]$ indicates $\mathrm{Ni}^{\mathrm{II}}$ with a spin state $S$ $=1$, whereas the inner $\mathrm{Ni}^{\mathrm{II}}$ atoms are four-coordinate and the short $\mathrm{Ni}-\mathrm{N}_{\text {amido }}$ distances [1.919(5) and 1.943(4) $\AA$ for $\mathrm{Ni}(2)-\mathrm{N}$ and $\mathrm{Ni}(5)-\mathrm{N}$, respectively] indicate $\mathrm{Ni}^{\mathrm{II}}$ atoms of a spin state $S=0$. The Ni-N distances in naphthyridyl units [2.002(5) $\AA$ for $\mathrm{Ni}(3)-\mathrm{N}$ and 2.010(4) $\AA$ for $\mathrm{Ni}(4)-\mathrm{N}]$ are consistent with the formation of mixed-valent species.

Molecule $\mathbf{2}$ is a straight line with a defined crystallographic symmetry. It has a fourfold symmetry with the central nickel atom at the symmetry center. Another twofold axis is perpendicular to the molecular chain. There are two equally occupied positions for $\mathrm{Ni}(4)$ and $\mathrm{Ni}(5)$, whereas $\mathrm{Ni}(1), \mathrm{Ni}(2)$, and $\mathrm{Ni}(3)$ are not disordered. Therefore, the molecule is oriented in two directions as: $\mathrm{Ni}(1 \mathrm{~A})-\mathrm{Ni}(2 \mathrm{~A})$ $\mathrm{Ni}(3 \mathrm{~A}) \cdots \mathrm{Ni}(5)-\mathrm{Ni}(4)-\mathrm{Ni}(3)-\mathrm{Ni}(2)-\mathrm{Ni}(1)$ and $\mathrm{Ni}(1 \mathrm{~A})-$ $\mathrm{Ni}(2 \mathrm{~A})-\mathrm{Ni}(3 \mathrm{~A})-\mathrm{Ni}(4 \mathrm{~A})-\mathrm{Ni}(5 \mathrm{~A}) \cdots \mathrm{Ni}(3)-\mathrm{Ni}(2)-\mathrm{Ni}(1)$, and each form is adopted with an occupancy of $50 \%$ [Figure 2, $\mathrm{Ni}(4 \mathrm{~A})$ and $\mathrm{Ni}(5 \mathrm{~A})$ are omitted]. The metal chain in $\mathbf{2}$ is defective because of one missing metal atom and consists of eight nickel atoms in a straight line with a $\mathrm{Ni}_{8}$ core. The $\mathrm{Ni}-\mathrm{Ni}$ distances range from 2.2520 to $2.4074 \AA$. The terminal distance $[\mathrm{Ni}(1)-\mathrm{Ni}(2)]$ is the longest and the distance between two $\mathrm{Ni}$ atoms bonded to naphthyridyl units [Ni(3)$\mathrm{Ni}(4)]$ is the shortest. The $\mathrm{Ni}(4)-\mathrm{Ni}(5)$ distance [2.351(3) $\AA$ ] is significantly longer than that in $\mathbf{1}[2.2817(6) \AA]$. The Ni$\mathrm{N}$ distance for the terminal nickel atom $[2.097(5) \AA$ for $\mathrm{Ni}(1)-\mathrm{N}]$ indicates $\mathrm{Ni}^{\mathrm{II}}$ with a spin state $S=1$, and all inner $\mathrm{Ni}-\mathrm{N}$ distances, ranging from $1.902(4)$ to $1.969(6) \AA$, indicate $\mathrm{Ni}^{\mathrm{II}}$ with a spin state $S=0$.
It is important to discuss the configuration of supporting ligands in EMACs 1 and 2. The torsion angles $\mathrm{N}-\mathrm{Ni}(1)-$ $\mathrm{Ni}(2)-\mathrm{N}$ in molecules $\mathbf{1}$ and $\mathbf{2}$ are $24.04^{\circ}$ and $22.25^{\circ}$, respectively, comparable with those in oligo- $\alpha$-pyridylamido EMAC $\left[\mathrm{Ni}_{9}\left(\mu_{9} \text {-peptea }\right)_{4} \mathrm{Cl}_{2}\right]$, but those related with 1,8 naphthyridine moieties [N-Ni(3)-Ni(4)-N] are much smaller (in the range $13.49-15.43^{\circ}$ for $\mathbf{1}$ and $15.82-19.16^{\circ}$ for 2 , respectively) because of the rigidity of fused rings. Consequently, the total torsion angle for one ligand, i.e. $\mathrm{N}-$ $\mathrm{Ni}(1)-\mathrm{Ni}(1 \mathrm{~A})-\mathrm{N}$, is obviously smaller than the average value for EMACs of oligo- $\alpha$-pyridyl/pyrazylamido ligands \{e.g. $133.8^{\circ}$ for $1,152.3^{\circ}$ for $2,166^{\circ}$ for $\left[\mathrm{Ni}_{9}\left(\mu_{9} \text {-peptea }\right)_{4} \mathrm{Cl}_{2}\right.$ ], and $159^{\circ}$ for $\left.\left[\mathrm{Cr}_{9}\left(\mu_{9}-\mathrm{N}_{9}-\mathrm{mpz}\right)_{4} \mathrm{Cl}_{2}\right]\right\}$. The observed larger value of total torsion angle of ligands in $\mathbf{2}$ is a result of one missing nickel atom, which diminishes the steric tension of the ligands. The helical conformation of the supporting ligands has been attributed to the repulsion between $\beta-\mathrm{H}$ atoms from the two adjacent aromatic rings, and the dihedral angle between adjacent pyridyl rings for oligo- $\alpha$-pyridylamido ligands is about $45^{\circ} .^{[10]}$ In the case of complexes 1 and 2, which lack a $\beta-\mathrm{H}$ on the pyrimidyl ring in ligand $\mathrm{H}_{3} \mathrm{~N}_{9}-2 \mathrm{pm}$, we found that the dihedral angle between pyrimidyl and 1,8-naphthyridyl rings were $48.6(2)^{\circ}$ for $\mathbf{1}$ and $50.8(2)^{\circ}$ for 2 , which are even larger than those reported for oligo- $\alpha$-pyridylamido and pyrazine-modulated oligo- $\alpha$ pyridylamido ligands. ${ }^{[6]}$

\section{Electrochemistry}

Previous experiments revealed that the tuning of ligands caused prominent changes in the electrochemical properties of their EMAC complexes, which are essential for their potential application as molecular devices and the nature of metal-metal bonding. The cyclic voltammogram of 1 recorded in $\mathrm{CH}_{2} \mathrm{Cl}_{2}$ revealed that $\mathbf{1}$ shows much more abundant redox properties than those of $\left[\mathrm{Ni}_{9}\left(\mu_{9} \text {-peptea }\right)_{4} \mathrm{Cl}_{2}\right]$, exhibiting four redox couples with one oxidative wave at $E_{1 / 2}=+0.308 \mathrm{~V}$ and three reductive waves at $E_{1 / 2}=+0.032$,

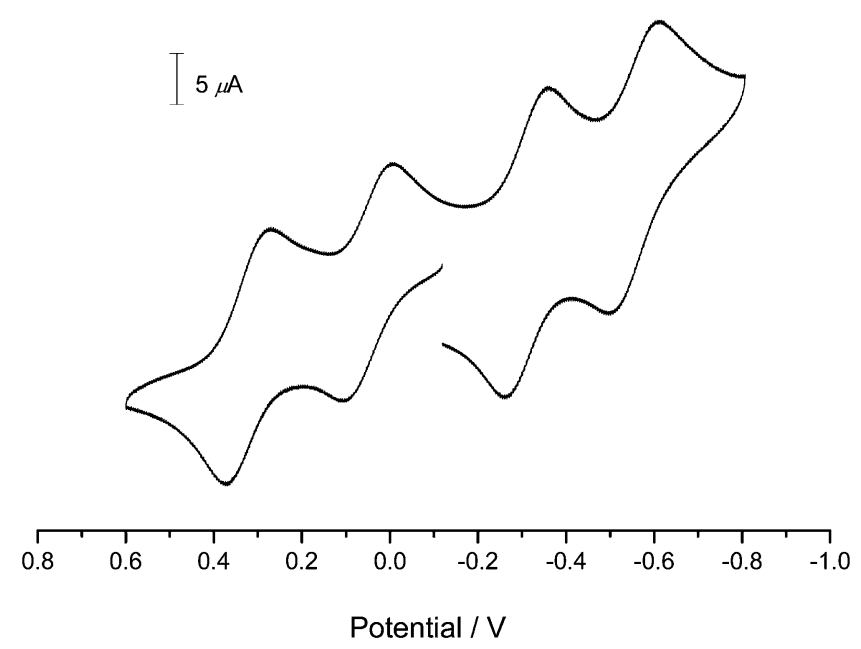

Figure 3. The cyclic voltammogram of $\mathbf{1}$ in $\mathrm{CH}_{2} \mathrm{Cl}_{2}$ with $0.1 \mathrm{M}$ tetra- $n$-butylammonium perchlorate (TBAP). 
-0.292 and $-0.536 \mathrm{~V}$ (Figure 3). ${ }^{[11]}$ Spectroelectrochemical techniques were used to determine the oxidation states of these electrochemical processes. For example, the redox couple at $E_{1 / 2}=+0.032 \mathrm{~V}$ is assigned to the reduction of $\mathrm{Ni}_{9}{ }^{16+}$ to form $\mathrm{Ni}_{9}{ }^{15+}$ (1 to $\mathbf{1}^{-}$) (Figure 4). All electrochemical processes are reversible and involve one-electron abstraction, which was evidenced by thin-layer spectroelectrochemical measurements.

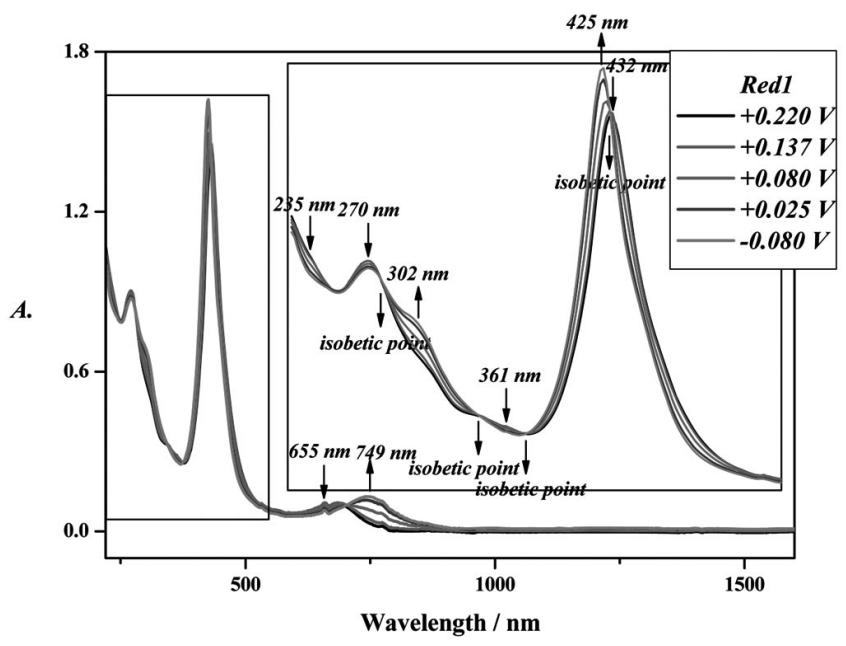

Figure 4. Electronic absorption spectral changes for the first reduction of 1 in $\mathrm{CH}_{2} \mathrm{Cl}_{2}$ containing TBAP at various applied potentials from -0.080 to $+0.220 \mathrm{~V}$.

\section{Magnetic Properties}

Magnetic susceptibility measurements were carried out over a temperature range of $2-300 \mathrm{~K}$ for complex $\mathbf{1}$ and 5$300 \mathrm{~K}$ for complex 2. The results are shown in Figure 5. The magnetism of $\mathbf{2}$ is attributed to a dinickel system with both terminal nickel atoms in a spin state $S=1$ and all other nickel atoms in a spin state $S=0$, as indicated by the bond lengths (Table 2). The observed $\chi_{M} T$ value is
$2.40 \mathrm{emu} \mathrm{K} \mathrm{mol}{ }^{-1}$ at room temperature $(300 \mathrm{~K})$, consistent with the structural results (spin-only for dinickel compound $\chi_{M} T=2.00 \mathrm{emu} \mathrm{Kmol}^{-1}$ ). Upon cooling, the $\chi_{M} T$ decreased slightly to a value of $1.89 \mathrm{emu} \mathrm{K} \mathrm{mol}^{-1}$ at $15 \mathrm{~K}$, indicating a weak antiferromagnetic coupling. Least-squares fitting with a theoretical expression for a dinuclear system deduced from the spin Hamiltonian equation $\mathbf{H}=-J S_{1} S_{2}$ $\left(S_{1}=S_{2}=1\right)$ resulted in a result of $g=2.03$ and $J=$ $-1.66 \mathrm{~cm}^{-1}$ with a TIP correction of $1.08 \times 10^{-3} \mathrm{emu} \mathrm{mol}^{-1}$. The rather small $J$ value suggests a quite weak magnetic interaction throughout the molecule of $\mathbf{2}$. Considering that the metal chain is defective because of one missing metal atom, the very weak magnetic interaction supports a pathway mainly through the central nickel chain, as our previous reports revealed. ${ }^{[7]}$ This study provides direct evidence for the metal chain pathway of magnetic superexchange coupling.

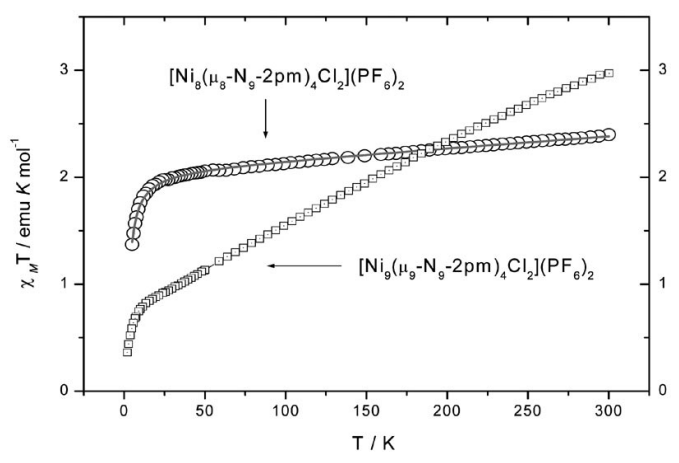

Figure 5. Plots of $\chi_{\mathrm{M}} T$ vs. $T$ for compounds 1 and $\mathbf{2}$. The solid line results from the least-squares fit.

A $\chi_{M} T$ value of $2.97 \mathrm{emu} \mathrm{K} \mathrm{mol}^{-1}$ was observed at room temperature $(300 \mathrm{~K})$ for $\mathbf{1}$. The crystal structure analysis showed that in nonanickel complex $\mathbf{1}$ both terminal nickel atoms are in a spin state $S=1$, all nickel atoms coordinated with amido nitrogen are in a spin state $S=0$, and the mixed valence binickel units, $\mathrm{Ni}_{2}{ }^{\mathrm{III}}$, are in a spin state $S=1 / 2$.

Table 2. Crystal data for compounds $\mathbf{1}$ and $\mathbf{2}$.

\begin{tabular}{lll}
\hline Compound & $\mathbf{1}$ & $\mathbf{2}$ \\
\hline Formula & {$\left[\mathrm{Ni}_{9}\left(\mu_{9}-\mathrm{N}_{9}-2 \mathrm{pm}\right)_{4} \mathrm{Cl}_{2}\right]\left(\mathrm{PF}_{6}\right)_{2} \cdot 3 \mathrm{C}_{2} \mathrm{H}_{5} \mathrm{OC}_{2} \mathrm{H}_{5} \cdot 4 \mathrm{CH}_{3} \mathrm{CN} \cdot \mathrm{H}_{2} \mathrm{O}$} & {$\left[\mathrm{Ni}_{8}\left(\mu_{8}-\mathrm{N}_{9}-2 \mathrm{pm}_{4} \mathrm{Cl}_{2}\right]\left(\mathrm{PF}_{6}\right)_{2} \cdot 14 \mathrm{CH}_{2} \mathrm{Cl}_{2}\right.$} \\
Formula weight & 3119.67 & 3845.33 \\
Crystal system & monoclinic & tetragonal \\
Space group & $C 2 / c$ & $P 4 / n n c$ \\
$a[\AA]$ & $27.6338(8)$ & $15.7333(3)$ \\
$b[\AA]$ & $28.5176(8)$ & $15.7333(3)$ \\
$c[\AA]$ & $19.3681(6)$ & $28.5334(6)$ \\
$\beta\left[^{\circ}\right]$ & $119.380(1)$ & 90 \\
Volume $\left[\AA^{3}\right], Z$ & $13300.0(7), 4$ & $7063.1(2), 2$ \\
Absorption coefficient $\left[\mathrm{mm}^{-1}\right]$ & 1.395 & 1.714 \\
Crystal size [mm] & $0.40 \times 0.13 \times 0.13$ & $0.25 \times 0.25 \times 0.18$ \\
$\theta$ range for data collection $\left[{ }^{\circ}\right]$ & $1.11-25.00$ & $1.43-27.50$ \\
Reflection collected & 37030 & 23625 \\
Independent reflections & $11700\left(R_{\text {int }}=0.0358\right)$ & $4079\left(R_{\text {int }}=0.0527\right)$ \\
$R_{1}$ & 0.0738 & 0.0763 \\
$R w_{2}[I>2 \sigma(I)]$ & 0.2568 & 0.2403 \\
$R_{1}$ & 0.1067 & 0.1128 \\
$R w_{2}$ (all data) & 0.2914 & 0.2733 \\
GOF & 1.078 & 1.058
\end{tabular}


Thus the magnetic contribution can be attributed to a tetranuclear system consisting of local spins $S=1,1 / 2,1 / 2$ and 1 with a theoretical spin-only $\chi_{M} T$ value of $2.75 \mathrm{emu} \mathrm{K} \mathrm{mol}{ }^{-1}$, which is consistent with the measurement results. As the temperature was lowered, $\chi_{\mathrm{M}} T$ decreased gradually to $0.75 \mathrm{emu} \mathrm{K} \mathrm{mol}^{-1}$ at $9 \mathrm{~K}$, indicating typical antiferromagnetic behavior. Below $7 \mathrm{~K}$, the $\chi_{\mathrm{M}} T$ value decreased sharply to $0.36 \mathrm{emu} \mathrm{K} \mathrm{mol}^{-1}$ at $2 \mathrm{~K}$ because of intermolecular interaction and zero-field splitting (ZFS). Although the simulation of experimental data was unsuccessful because of the absence of a proper theoretical expression, the rate of decrease of $\chi_{\mathrm{M}} T$ is significantly larger for $\mathbf{1}$ than for $\mathbf{2}$ and indicates a much stronger magnetic coupling in molecule $\mathbf{1}$. It should be mentioned that the EPR spectrum of $\mathbf{1}$ is silent.

\section{Conclusions}

In summary, using the new pyrimidyl- and naphthyridylmodulated oligo- $\alpha$-pyridylamino ligand $\mathrm{H}_{3} \mathrm{~N}_{9}-2 \mathrm{pm}$, we have successfully obtained single crystals of a high-yield, two-electron reduced nonanickel EMAC and a defective octanuclear EMAC. Nonanickel complex 1 contains two fully delocalized, mixed-valence $\left[\mathrm{Ni}_{2}(\text { napy })_{4}\right]^{3+}$ units. The magnetic properties of the defective octanuclear complex $2 \mathrm{dem}-$ onstrate that the metal chain provides a pathway of magnetic superexchange coupling in the EMAC.

\section{Experimental Section}

Materials: All reagents and solvents were obtained from commercial sources and were used without further purification unless otherwise noted. The $\mathrm{CH}_{2} \mathrm{Cl}_{2}$ used for electrochemistry was freshly distilled prior to use. Tetra- $n$-butylammonium perchlorate (TBAP) was recrystallized twice from ethyl acetate and dried under vacuum.

Physical Measurements: Absorption spectra were recorded with a Hewlett Packard 8453 spectrophotometer. IR spectra were obtained with a Perkin-Elmer FT-IR Spectrometer PARAGON 1000 in the range $400-4000 \mathrm{~cm}^{-1}$. The ${ }^{1} \mathrm{H}$ NMR spectroscopic data were recorded with a Bruker AMX400 spectrometer in $\left(\mathrm{CD}_{3}\right)_{2} \mathrm{SO}$, and chemical shifts are reported in ppm relative to $\left(\mathrm{CD}_{3}\right)_{2} \mathrm{SO}(\delta=$ $2.49 \mathrm{ppm}$ for $\left.{ }^{1} \mathrm{H}\right)$. FAB-MS mass spectra were obtained with a JEOL JMS-700 HF double focusing spectrometer operating in the positive-ion detection mode. Molar magnetic susceptibility was recorded by using a SQUID system with a 2000 -Gauss external magnetic field. Electrochemistry was performed with a three-electrode potentiostat $(\mathrm{CH}$ Instruments, Model $750 \mathrm{~A})$ in $\mathrm{CH}_{2} \mathrm{Cl}_{2}$ deoxygenated by purging with prepurified nitrogen gas. Cyclic voltammetry was conducted with the use of a home-made three-electrode cell equipped with a BAS glassy carbon $\left(0.07 \mathrm{~cm}^{2}\right)$ or platinum $\left(0.02 \mathrm{~cm}^{2}\right)$ disk as the working electrode, a platinum wire as the auxiliary electrode, and a home-made $\mathrm{Ag} / \mathrm{AgCl}$ (saturated) reference electrode. The reference electrode is separated from the bulk solution by a double junction filled with electrolyte solution. Potentials are reported vs. $\mathrm{Ag} / \mathrm{AgCl}$ (saturated) and referenced to the ferrocene/ferrocenium $\left(\mathrm{Fc} / \mathrm{Fc}^{+}\right)$couple which occurs at $E_{1 / 2}=+0.54$ $\mathrm{V}$ vs. $\mathrm{Ag} / \mathrm{AgCl}$ (saturated). The working electrode was polished with $0.03 \mu \mathrm{M}$ aluminum on Buehler felt pads and was subjected to ultrasonic radiation for $1 \mathrm{~min}$ prior to each experiment. The reproducibility of individual potential values was within $\pm 5 \mathrm{mV}$.
The spectroelectrochemical experiments were accomplished with the use of a $1 \mathrm{~mm}$ cuvette, a 100 mesh platinum gauze as working electrode, a platinum wire as the auxiliary electrode, and a $\mathrm{Ag} / \mathrm{AgCl}$ (saturated) reference electrode.

\section{Preparation of Compounds}

$N^{2}$-(Pyrimidin-2-yl)- $N^{7}$-[2-(pyrimidin-2-ylamino)-1,8-naphthyridin7-yll-1,8-naphthyridine-2,7-diamine $\left(\mathbf{H}_{3} \mathbf{N}_{\mathbf{9}}-\mathbf{2 p m}\right)$ : The reaction of bis(2-chloro-1,8-naphthyridin-7-yl)amine $(6.0 \mathrm{~g}, 17.5 \mathrm{mmol})$ and 2aminopyrimidine $(4.0 \mathrm{~g}, 42 \mathrm{mmol})$ in the presence of $\mathrm{Pd}_{2}(\mathrm{dba})_{3}$ $(0.64 \mathrm{~g}, 4 \mathrm{~mol}-\%)$, BINAP $(0.87 \mathrm{~g}, 8 \mathrm{~mol}-\%)$, and $t \mathrm{BuONa}(5.7 \mathrm{~g}$, $59 \mathrm{mmol}$ ) in toluene $(300 \mathrm{~mL})$ for $96 \mathrm{~h}$ gave $\mathrm{H}_{3} \mathrm{~N}_{9}-2 \mathrm{pm}$. The crude product was recrystallized from dmf/ethyl acetate (1:20) and gave pure $\mathrm{H}_{3} \mathrm{~N}_{9}-2 \mathrm{pm}$ as a yellow-orange solid. Yield $6.5 \mathrm{~g}(80 \%)$. IR $(\mathrm{KBr}): \tilde{v}=3365(\mathrm{~m}), 3226(\mathrm{~m}), 3040(\mathrm{~m}), 1599$ (s), 1582 (s), 1559 (m), 1520 (m), 1496 (s), 1448 (s), 1418 (s), 1380 (m), 1334 (s), 1254

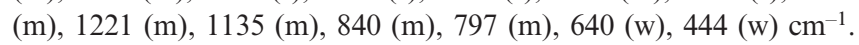
UV/Vis $\quad(\mathrm{dmf}) \quad \lambda \quad\left(\varepsilon / \mathrm{dm}^{3} \mathrm{~mol}^{-1} \mathrm{~cm}^{-1}\right): \quad 273 \quad\left(3.22 \times 10^{4}\right), \quad 332$ $\left(6.01 \times 10^{3}\right), 348\left(1.22 \times 10^{4}\right) \mathrm{nm} .{ }^{1} \mathrm{H}$ NMR [400 MHz, $\left(\mathrm{CD}_{3}\right)_{2} \mathrm{SO}$, $\left.25^{\circ} \mathrm{C}\right]: \delta=10.60(\mathrm{~s}, 1 \mathrm{H}), 10.25(\mathrm{~s}, 2 \mathrm{H}), 8.60-8.58(\mathrm{~m}, 4 \mathrm{H}), 8.39$ $8.37(\mathrm{~d}, J=8.80 \mathrm{~Hz}, 2 \mathrm{H}), 8.19-8.18(\mathrm{~m}, 4 \mathrm{H}), 8.17-8.12(\mathrm{~d}, J=$ $18.8 \mathrm{~Hz}, 2 \mathrm{H}), 7.02-6.99(\mathrm{t}, J=10.0 \mathrm{~Hz}, 2 \mathrm{H}) \mathrm{ppm}$. MS (FAB): $m / z(\%)=460(45)[\mathrm{M}]^{+} . \mathrm{C}_{24} \mathrm{H}_{23} \mathrm{~N}_{11} \mathrm{O}_{3}\left[\mathrm{H}_{3} \mathrm{~N}_{9}-2 \mathrm{pm} \cdot 3 \mathrm{H}_{2} \mathrm{O}\right](513.51)$ : calcd. C 56.13, H 4.51, N 30.00; found C 55.79, H 4.09, N 29.60.

$\left[\mathbf{N i}_{9}\left(\boldsymbol{\mu}_{\mathbf{9}}-\mathbf{N}_{\mathbf{9}}-\mathbf{2} \mathbf{p m}\right)_{\mathbf{4}} \mathbf{C l}_{\mathbf{2}}\right]\left(\mathbf{P F}_{\mathbf{6}}\right)_{\mathbf{2}}$ (1): A mixture of anhydrous $\mathrm{NiCl}_{2}$ (305 mg, $2.35 \mathrm{mmol}), \mathrm{H}_{3} \mathrm{~N}_{9}-2 \mathrm{pm}(400 \mathrm{mg}, 0.87 \mathrm{mmol}$ ), and naphthalene $(65 \mathrm{~g})$ was boiled overnight $\left(220^{\circ} \mathrm{C}\right)$ under argon. Then a solution of potassium tert-butoxide $(337 \mathrm{mg}, 3.0 \mathrm{mmol})$ in $n$-butyl alcohol $(4 \mathrm{~mL})$ was added dropwise. After reaction $n$-hexane $(300 \mathrm{~mL})$ was added to wash out the naphthalene. Compound 1 was extracted with $\mathrm{CH}_{2} \mathrm{Cl}_{2}(200 \mathrm{~mL})$. After evaporation of the solvent a greenish brown complex was obtained. The solid product was stirred for $1 \mathrm{~h}$ at $60{ }^{\circ} \mathrm{C}$ in benzene $(300 \mathrm{~mL})$ to remove $\left[\mathrm{Ni}_{8}\left(\mu_{8^{-}}\right.\right.$ $\left.\left.\mathrm{N}_{9}-2 \mathrm{pm}\right)_{4} \mathrm{Cl}_{2}\right]\left(\mathrm{PF}_{6}\right)_{2}$. Then it was filtered. Single crystals suitable for X-ray diffraction studies were obtained by diffusion of diethyl ether into a $\mathrm{CH}_{2} \mathrm{Cl}_{2}-\mathrm{CH}_{3} \mathrm{CN}$ (1:1) solution. Yield $130 \mathrm{mg}(22 \%)$. IR (KBr): $\tilde{v}=3448(\mathrm{~s}), 1684(\mathrm{~m}), 1654(\mathrm{~m}), 1616(\mathrm{~m}), 1582(\mathrm{~m})$, 1560 (s), 1540 (m), $1522(\mathrm{~m}), 1507$ (m), 1457 (m), 1419 (s), 1346 (m), 1292 (m), $1154(\mathrm{~m}), 848$ (m), $788(\mathrm{w}), 668(\mathrm{w}), 418(\mathrm{~m}) \mathrm{cm}^{-1}$. UV/Vis $\left(\mathrm{CH}_{2} \mathrm{Cl}_{2}\right) \quad \lambda\left(\varepsilon / \mathrm{dm}^{3} \mathrm{~mol}^{-1} \mathrm{~cm}^{-1}\right): 232\left(1.52 \times 10^{5}\right), 271$ $\left(1.48 \times 10^{5}\right), 433\left(2.02 \times 10^{5}\right), 665\left(1.38 \times 10^{4}\right) \mathrm{nm}$. MS (MALDI): $\mathrm{m} / \mathrm{z}(\%)=2351 \quad(55)[\mathrm{M}-2 \mathrm{Cl}]^{+}, 2423(100)[\mathrm{M}]^{+}$. $\mathrm{C}_{96} \mathrm{H}_{62} \mathrm{Cl}_{2} \mathrm{~N}_{44} \mathrm{Ni}_{9} \mathrm{P}_{2} \mathrm{~F}_{12} \mathrm{O}_{3}\left[1 \cdot 3 \mathrm{H}_{2} \mathrm{O}\right]$ (2768.89): calcd. C 41.64, $\mathrm{H}$ 2.26, N 22.26; found C 41.39, H 2.56, N 21.94.

$\left[\mathbf{N i}_{\mathbf{8}}\left(\boldsymbol{\mu}_{\mathbf{8}}-\mathbf{N}_{\mathbf{9}}-\mathbf{2} \mathbf{p m}\right)_{\mathbf{4}} \mathbf{C l}_{\mathbf{2}}\right]\left(\mathbf{P F}_{\mathbf{6}}\right)_{\mathbf{2}}$ (2): A mixture of anhydrous $\mathrm{NiCl}_{2}$ (280 mg, $2.16 \mathrm{mmol}), \mathrm{H}_{3} \mathrm{~N}_{9}-2 \mathrm{pm}(400 \mathrm{mg}, 0.87 \mathrm{mmol})$, and naphthalene $(60 \mathrm{~g})$ was heated $\left(160-170^{\circ} \mathrm{C}\right)$ overnight under argon. Then a solution of potassium tert-butoxide $(293 \mathrm{mg}, 2.61 \mathrm{mmol})$ in $n$-butyl alcohol (4 mL) was added dropwise. After reaction $n$-hexane $(300 \mathrm{~mL})$ was added to wash out the naphthalene. Compound 2 was extracted with benzene $(200 \mathrm{~mL})$ and recrystallized from hexane $/ \mathrm{CH}_{2} \mathrm{Cl}_{2}$ (4:1). Deep brown crystals were obtained. Yield $92.5 \mathrm{mg}$ (16\%). IR (KBr): $\tilde{v}=3419(\mathrm{w}), 1583(\mathrm{~m}), 1558(\mathrm{~m}), 1538$ (m), 1496 (s), 1442 (m), 1418 (m), 1332 (s), 1293 (m), 1146 (m), 846 (w), 789 (w), 668 (w), 557 (w) $\mathrm{cm}^{-1}$. UV/Vis $\left(\mathrm{CH}_{2} \mathrm{Cl}_{2}\right) \lambda$ $\left(\varepsilon / \mathrm{dm}^{3} \mathrm{~mol}^{-1} \mathrm{~cm}^{-1}\right): \quad 233 \quad\left(1.30 \times 10^{5}\right), \quad 263 \quad\left(1.34 \times 10^{5}\right), \quad 439$ $\left(1.51 \times 10^{5}\right), 636\left(6.84 \times 10^{3}\right) \mathrm{nm}$. MS (MALDI): $\mathrm{m} / \mathrm{z}(\%)=2296$ (70) $[\mathrm{M}-2 \mathrm{Cl}]^{+}, 2364(32)[\mathrm{M}]^{+} . \mathrm{C}_{102} \mathrm{H}_{70} \mathrm{Cl}_{2} \mathrm{~N}_{44} \mathrm{Ni}_{8} \mathrm{P}_{2} \mathrm{~F}_{12}\left[2 \cdot \mathrm{C}_{6} \mathrm{H}_{14}\right]$ (2742.32): calcd. C 44.67, H 2.57, N 22.47; found C 44.28, H 2.49, N 22.26 .

Crystal Structure Determinations: The chosen crystals were mounted on a glass fiber. Data collection was carried out with a NONIUS Kappa CCD diffractometer at 150 (2) K by using Mo- $K_{\alpha}$ 
radiation $(\lambda=0.71073 \AA)$ and a liquid nitrogen low-temperature controller. Cell parameters were retrieved and refined with the DENZO-SMN software on all reflections. Data reduction was performed on the DENZO-SMN software. Semiempirical absorption was based on symmetry-equivalent reflections, and absorption corrections were applied with the DENZO-SMN program. All the structures were solved with SHELXS-97 and refined with SHELXL-97 by full-matrix least-squares on $F^{2}$ values. ${ }^{[12,13]}$ The crystal data for compounds $\mathbf{1}$ and $\mathbf{2}$ are listed in Table 2. CCDC674816 and CCDC-674817 contain the supplementary crystallographic data of compounds $\mathbf{1}$ and $\mathbf{2}$ for this paper. These data can be obtained free of charge from the Cambridge Crystallographic Data Centre via www.ccdc.cam.ac.uk/data_request/cif.

Supporting Information (see also the footnote on the first page of this article): Synthesis of the starting material bis(2-chloro-1,8naphthyridin-7-yl)amine.

\section{Acknowledgments}

The authors thank the National Science Council of the Republic of China for financial support and Mr. Wei-Min Lee for his help with magnetic measurements.

[1] a) J. F. Berry, F. A. Cotton, L. M. Daniels, C. A. Murillo, J. Am. Chem. Soc. 2002, 124, 3212-3213; b) S.-Y. Lin, I.-W. P. Chen, C.-H. Chen, M.-H. Hsieh, C.-Y. Yeh, T.-W. Lin, Y.-H. Chen, S.-M. Peng, J. Phys. Chem. B 2004, 108, 959-964; c) I.W. P. Chen, M.-D. Fu, W.-H. Tseng, J.-Y. Yu, S.-H. Wu, C.-J. $\mathrm{Ku}$, C.-H. Chen, S.-M. Peng, Angew. Chem. Int. Ed. 2006, 45, 5814-5818.

[2] a) C.-K. Kuo, J.-C. Chang, C.-Y. Yeh, G.-H. Lee, C.-C. Wang, S.-M. Peng, Dalton Trans. 2005, 3696-3701; b) B. Bénard, J. F. Berry, F. A. Cotton, C. Gaudin, X. López, C. A. Murillo, M.M. Rohmer, Inorg. Chem. 2006, 45, 3932-3940; c) J. F. Berry, F. A. Cotton, T. Lu, C. A. Murillo, B. K. Roberts, X. Wang, J. Am. Chem. Soc. 2004, 126, 7082-7096; d) R. Clérac, F. A. Cotton, L. M. Daniels, K. R. Dunbar, C. A. Murillo, I. Pascual, Inorg. Chem. 2000, 39, 752-756; e) J. F. Berry, F. A. Cotton, L. M. Daniels, C. A. Murillo, X. Wang, Inorg. Chem. 2003, 42, 2418-2427.

[3] a) F. A. Cotton, L. M. Daniels, C. A. Murillo, X. Wang, Chem. Commun. 1998, 39-40; b) S.-Y. Lai, T.-W. Lin, Y.-H. Chen, C.-
C. Wang, G.-H. Lee, M.-H. Yang, M.-K. Leung, S.-M. Peng, J. Am. Chem. Soc. 1999, 121, 250-251.

[4] a) H.-C. Chang, J.-T. Li, C.-C. Wang, T.-W. Lin, H.-C. Lee, G.H. Lee, S.-M. Peng, Eur. J. Inorg. Chem. 1999, 1243-1251; b) J. F. Berry, F. A. Cotton, C. S. Fewox, T. Lu, C. A. Murillo, X. Wang, Dalton Trans. 2004, 2297-2302; c) C.-Y. Yeh, Y.-L. Chiang, G.-H. Lee, S.-M. Peng, Inorg. Chem. 2002, 41, 40964098; d) C.-Y. Yeh, C.-H. Chou, K.-C. Pan, C.-C. Wang, G.H. Lee, Y. O. Su, S.-M. Peng, J. Chem. Soc., Dalton Trans. 2002, 2670-2677; e) J. F. Berry, F. A. Cotton, P. Lei, T. Lu, C. A. Murillo, Inorg. Chem. 2003, 42, 3534-3539.

[5] a) Y.-H. Chen, C.-C. Lee, C.-C. Wang, G.-H. Lee, S.-Y. Lai, S.M. Peng, Chem. Commun. 1999, 1667-1668; b) S.-Y. Lai, C.C. Wang, Y.-H. Chen, C.-C. Lee, Y.-H. Liu, S.-M. Peng, J. Chin. Chem. Soc. 1999, 46, 477-485; c) W.-Z. Wang, R. H. Ismayilov, G.-H. Lee, I. P.-C. Liu, C.-Y. Yeh, S.-M. Peng, Dalton Trans. 2007, 830-839.

[6] a) S.-M. Peng, C.-C. Wang, Y.-L. Jang, Y.-H. Chen, F.-Y. Li, C.-Y. Mou, M.-K. Leung, J. Magn. Magn. Mater. 2000, 209, 80-83; b) R. H. Ismayilov, W.-Z. Wang, R.-R. Wang, C.-Y. Yeh, G.-H. Lee, S.-M. Peng, Chem. Commun. 2007, 1121-1123.

[7] R. H. Ismayilov, W.-Z. Wang, G.-H. Lee, R.-R. Wang, I. P.-C. Liu, C.-Y. Yeh, S.-M. Peng, Dalton Trans. 2007, 2898-2907.

[8] a) L. Sacconi, C. Mealli, D. Gatteschi, Inorg. Chem. 1974, 13, 1985-1991; b) A. Bencini, E. Berti, A. Caneschi, D. Gatteschi, E. Giannasi, I. Invernizzi, Chem. Eur. J. 2002, 8, 3660-3670.

[9] a) C.-H. Chien, J.-C. Chang, C.-Y. Yeh, G.-H. Lee, J.-M. Fang, Y. Song, S.-M. Peng, Dalton Trans. 2006, 3249-3256; b) C.-H. Chien, J.-C. Chang, C.-Y. Yeh, G.-H. Lee, J.-M. Fang, S.-M. Peng, Dalton Trans. 2006, 2106-2113; c) T.-B. Tsao, S.-S. Luo, C.-Y. Yeh, G.-H. Lee, S.-M. Peng, Polyhedron 2007, 26, 3833 3841.

[10] a) R. Clérac, F. A. Cotton, L. M. Daniels, K. R. Dunbar, C. A. Murillo, I. Pascual, Inorg. Chem. 2000, 39, 748-751; b) F. A. Cotton, P. Lei, C. A. Murillo, Inorg. Chim. Acta 2003, 349, 173-181.

[11] C.-Y. Yeh, C.-C. Wang, Y.-H. Chen, S.-M. Peng, Redox Systems under Nano-Space Control (Ed.: T. Hirao), Springer, Berlin, 2006, ch. 5.

[12] G. M. Sheldrick, SHELXS-97, Program for Solution of Crystal Structures, University of Göttingen, 1997.

[13] G. M. Sheldrick, SHELXL-97, Program for Refinement of Crystal Structures, University of Göttingen, 1997.

Received: May 5, 2008

Published Online: August 22, 2008 